ALINA BtASZCZYK

Uniwersytet Łódzki, Polska - University of Lodz, Poland

\title{
Znaczenie edukacji w zakresie przedsiębiorczości
}

\section{The Importance of Entrepreneurship Education}

Streszczenie: Celem podjętych rozważań jest analiza literatury z zakresu badań nad edukacją ekonomiczną i przedstawienie postawy uczniów wobec przedmiotu podstawy przedsiębiorczości. W artykule omówiono dotychczasowe badania nad stosunkiem uczniów, nauczycieli i rodziców do tego przedmiotu po jego wprowadzeniu do szkół ponadgimnazjalnych. Zaprezentowane zostały w nim również wyniki badań ankietowych dotyczące umiejętności przedsiębiorczych, przeprowadzonych w pięciu liceach ogólnokształcących zróżnicowanych profilowo w województwie łódzkim w roku szkolnym 2017/2018. Zróżnicowanie profilowe szkół pozwala zauważyć posiadanie innych umiejętności przedsiębiorczych u uczniów oraz wykorzystanie edukacji ekonomicznej w przyszłości. Według uczniów podstawy przedsiębiorczości mają niską rangę w szkole, ponieważ nie jest to przedmiot maturalny. Ze względu na niską świadomość ekonomiczną Polaków (Klapper, 2015) rozwijanie wiedzy ekonomicznej powinno trwać przez całe życie i rozpocząć się jak najwcześniej. Najlepiej, aby wdrażane było już w szkole podstawowej, a następnie w szkole ponadpodstawowej. Wskazane byłoby, aby ekonomia była jednym z przedmiotów do wyboru na maturze, wówczas ten przedmiot miałby większą rangę.

\begin{abstract}
The aim of the study is to analyse the literature on the research of economic education and present the attitude of the students towards the subject matter of the entrepreneurship. The article discusses the current research on the relationship of pupils, teachers and parents to this subject after its introduction to the high schools. It will also present the results of surveys conducted in five high schools in lodzki province for the 2017/2018 school year on entrepreneurial skills. The profile diversity of schools also allows to see possession of pupils' entrepreneurial skills and the use of economic education in the future. According to the students, the basics of entrepreneurship are low in school because it is not a promoted subject. Due to the low economic awareness of Polish people, developing economic knowledge should last a lifetime and begin as early as possible. It is the best to be implemented in elementary school and then in secondary school. It would be advisable for the economy to be one of the subjects to choose from the graduation, then this one would have a higher rank.
\end{abstract}

Słowa kluczowe: edukacja; ekonomia w praktyce; nauczyciel; podstawy przedsiębiorczości; reforma edukacji

Key words: economics in practice; education; education reform; Basics of Entrepreneurship; teacher 
Otrzymano: 14 listopada 2018

Received: 14 November 2018

Zaakceptowano: 28 lutego 2019

Accepted: 28 February 2019

\section{Sugerowana cytacja/Suggested citation:}

Błaszczyk, A. (2019). Znaczenie edukacji w zakresie przedsiębiorczości. Przedsiębiorczość Edukacja [Entrepreneurship - Education], 15(1), 19-33. doi: 10.24917/20833296.151.2

\section{Wstęp}

Po reformie oświaty przeprowadzonej w 1999 r. powstały trzyletnie licea ogólnokształcące i czteroletnie technika. Od 1 września 2002 r. do szkół ponadgimnazjalnych został wprowadzony nowy przedmiot - podstawy przedsiębiorczości - jako odpowiedź na zachodzące po transformacji w kraju przemiany społeczno-gospodarcze. Zajęcia prowadzone w wymiarze 2 godz. tygodniowo w cyklu trzyletnim miały wykształcić kompetentnego, innowacyjnego i przedsiębiorczego człowieka.

Od roku szkolnego 2009/2010 w szkołach wprowadzono reformę programową, w której przewidziane były zmiany związane z rozszerzeniem edukacji na rzecz przedsiębiorczości. Od roku szkolnego 2012/2013 przedmiot podstawy przedsiębiorczości realizowany jest tylko w zakresie podstawowym, a dodatkowo został wprowadzony nowy przedmiot uzupełniający ekonomia w praktyce. Nowy przedmiot miał służyć kształtowaniu postaw i zachowań przedsiębiorczych. Jest to przedmiot bardziej praktyczny. Zalecaną formą pracy jest projekt. Przedmiot ten może być realizowany równolegle z podstawami przedsiębiorczości bądź jako kontynuacja po podstawach przedsiębiorczości.

W sierpniu 2018 r. została podpisana nowa podstawa programowa dla podstaw przedsiębiorczości, w której treści nauczania były podzielone cztery działy:

- gospodarka rynkowa - 8 godz.

- rynek finansowy - 13 godz.

- rynek pracy - 12 godz.

- przedsiębiorstwo - 19 godz.

Do dyspozycji nauczyciela pozostało 8 godz.

Celem niniejszego artykułu jest analiza literatury w zakresie badań nad edukacją ekonomiczną i przedstawienie postawy uczniów wobec przedmiotu podstawy przedsiębiorczości. W artykule omówione zostały dotychczasowe badania nad stosunkiem uczniów, nauczycieli i rodziców do tego przedmiotu po jego wprowadzeniu do szkół ponadgimnazjalnych oraz zaprezentowano wyniki badań ankietowych przeprowadzonych w pięciu liceach ogólnokształcących zróżnicowanych profilowo w województwie łódzkim w roku szkolnym 2017/2018, dotyczące działań i umiejętności przedsiębiorczych. W artykule uwzględnione zostały wyniki raportu Komisji Europejskiej w zakresie przedsiębiorczości.

\section{Z nowym przedmiotem nowe wyzwania}

„W latach 1999-2009 treści z przedsiębiorczości były realizowane na poziomie gimnazjum w ramach lekcji wiedzy o społeczeństwie oraz w szkole ponadgimnazjalnej, jako oddzielny przedmiot w wymiarze dwóch godzin w trzyletnim cyklu kształcenia. 
Od 1 września 2009 r., kiedy w szkole ponadgimnazjalnej wprowadzono koncepcję kształcenia profilowanego, ranga tego przedmiotu wzrosła. Uczniowie klas pierwszych szkół ponadgimnazjalnych realizują kształcenie w zakresie przedsiębiorczości w wymiarze dwóch godzin tygodniowo, a więc większym niż przedmioty przyrodnicze: biologia, fizyka, chemia i geografia oraz społeczne: wiedza o społeczeństwie, na których realizację przeznaczono jedną godzinę tygodniowo" (Nauczanie podstaw przedsiębiorczości..., 2012).

Po wprowadzeniu od 2002 r. nowego przedmiotu do szkół ponadgimnazjalnych pojawiły się nowe wyzwania dla nauczycieli. Aby efektywnie wykorzystać przedmioty podstawy przedsiębiorczości czy ekonomia w praktyce, nauczyciel prowadzący powinien mieć dużą wiedzę, m.in. z zakresu ekonomii i zarządzania. Z zebranych danych wynika, że nauczyciele nie czują się pewnie w pracy z nowym programem i przedmiotem. Nauczyciel powinien testować innowacyjne metody nauczania przedsiębiorczości i realizować je np. z wykorzystaniem studiów przypadku czy też metodą projektową, problemową, a nie wykładową. Nauczyciel powinien „umieć rozbudzić pozytywne nastawienie uczniów do przedsiębiorczości - uświadomić młodym osobom, że postawy przedsiębiorcze zaprocentują w przyszłości, wpływając na poprawę warunków ich życia” (Dąbrowski, 2011). Dobrze byłoby, aby uczeń, który kończy szkołę ponadgimnazjalną, miał wyrobione postawy i zachowania przedsiębiorcze, które przydadzą mu się w każdej pracy i w całym dorosłym życiu. Dlatego do tego potrzebny jest odpowiednio przygotowany nauczyciel. W $2011 \mathrm{r}$. „niektóre uczelnie ekonomiczne zadeklarowały, że uruchomią kształcenie nauczycieli na potrzeby szkół, jeśli Ministerstwo Edukacji Narodowej włączy podstawy przedsiębiorczości do przedmiotów maturalnych" (Dąbrowski, 2012: 169).

Przedsiębiorczy nauczyciel według Z. Kurka (2001) powinien:

- poszukiwać nowych i innowacyjnych metod nauczania,

- stosować pobudzające metody kształcenia,

- uzupełniać i poszerzać zasób kształtowanych umiejętności oraz własne kompetencje, które mogą być zastosowane w praktyce,

- być doradcą, konsultantem, a nawet liderem,

- być tolerancyjny i otwarty na potrzeby uczniów,

- dawać wyraz pozytywną postawą i oddziaływać na uczniów motywująco,

- stwarzać uczniom okazję uczenia się przez czyny,

- dążyć do bycia pozytywnie odbieranym przez uczniów.

Z. Kurek (2001) zwrócił również uwagę na fakt, że nauczyciel w kryteriach oceniania powinien uwzględnić:

- pomysłowość, kreatywność, innowacyjność oraz zdolność kreacji,

- aktywność i zaangażowanie,

- zdolność analizowania faktów i wyciągania wniosków z popełnianych błędów,

- rzetelność, odpowiedzialność, sumienność i stanowczość,

- samodzielną precyzję definiowania osądów i podejmowania ustaleń,

- umiejętności zdobywania i wykorzystywania zdobytej wiedzy,

- umiejętność współpracy i specyfikę danej grupy,

- rozwój kształconych umiejętności,

- praktykę zdobytą w szkole i poza nią.

Poważnym błędem stosowanym przez nauczycieli jest sprawdzanie pamięciowego opanowania abstrakcyjnych teorii, prawidłowości i pojęć. W ten sposób trudno jest 
dowiedzieć się, czy uczeń opanował dane zagadnienie. Bardzo często uczniowie potrafią zdefiniować wiele pojęć, ale nie potrafią wykorzystać ich w praktyce.

\section{Analiza dotychczasowych badań}

Do jednych z pierwszych badań związanych z wprowadzeniem nowego przedmiotu podstawy przedsiębiorczości - do szkół należą badania E. i W. Osuchów (Osuch E., Osuch W., 2005) przeprowadzone w 2004 roku. Objęły one uczniów (165 ankiet) i rodziców (115 ankiet) z trzech krakowskich liceów ogólnokształcących. Uzyskane dane potwierdziły wysoką aprobatę społeczną dla przedmiotu podstawy przedsiębiorczości w szkole, ukazaną przez uczniów i rodziców (91\% badanych) oraz częste zapewnienia uczniów dotyczące zainteresowania poznawaną tematyką i jej praktycznym wykorzystaniem w życiu.

Jednakowo ważnych informacji o realizacji edukacji przedsiębiorczej w szkołach ponadgimnazjalnych dostarczył w 2005 r. raport opracowany przez Centralny Ośrodek Doskonalenia Nauczycieli w Warszawie (Raport zbiorowy..., 2005). Zebrane w nim dane są dowodem na to, że przedmiot podstawy przedsiębiorczości ma raczej niską rangę w szkole. Dla nauczycieli ma większe znaczenie w procesie kształcenia niż dla uczniów oraz dyrektorów szkół. Jest to jasne, gdyż związane jest to z ich zatrudnieniem, ale może również świadczyć o dużej pasji i zaangażowaniu nauczycieli w nauczanie tego przedmiotu.

Wyniki badań przeprowadzonych przez Wiktora Osucha (Osuch, 2011) w tych samych krakowskich szkołach ponadgimnazjalnych w 2011 r. uwidoczniły zasadnicze rozbieżności w ocenie przedmiotu podstawy przedsiębiorczości przez uczniów i rodziców. Badaniem została objęta podobna grupa uczniów i rodziców, tak jak w 2004 r. Zauważono jednak niższe wyniki dotyczące słuszności i celności wprowadzenia przedmiotu do szkoły ponadgimnazjalnej niż w 2004 r. Potwierdzane zainteresowanie zgłębianymi treściami z podstaw przedsiębiorczości nie uległo dużym zmianom, ale znacznie mniej uczniów miało zadanie, że posłuży się tą wiedzą i umiejętności w dalszym życiu. Badania te pokazały także niejednolite i odmienne zainteresowanie uczniów treściami nauczania - ujawniły się zagadnienia interesujące i wywołujące dużą ciekawość młodzieży. Są to ważne informacje dla nauczycieli podstaw przedsiębiorczości w tych szkołach, ponieważ przedstawiają i obrazują one problem w nauczaniu treści z tego obszaru.

Interesujące dane zostały zebrane w wyniku badań ankietowych na przełomie 2010/2011 r. przeprowadzonych przez K. Kuklińską i P. Moranowskiego w 232 szkołach ponadgimnazjalnych (Kuklińska, Moranowski, 2009). Opublikowany raport z tychże badań ujawnił, że zainteresowanie uczniów przedmiotem podstawy przedsiębiorczości jest wyższe w ocenie nauczycieli niż w ocenie samych uczniów (rycina 1). Powyżej 31\% nauczycieli wskazało na bardzo wysokie zainteresowanie uczniów przedmiotem, a prawie 59\% uważało je za wysokie. Tylko 13,1\% uczniów uznało, że przedmiot ten jest dla nich „zdecydowanie interesujący”, a 43,4\% oceniło go jako „raczej interesujący”. W ocenie połowy ankietowanych uczniów naukę, którą zdobywają na zajęciach z podstaw przedsiębiorczości, mogą wykorzystać w dalszym życiu bądź karierze zawodowej. Około 33\% uczniów zdecydowanie stwierdziło, że wiedza ta będzie im przydatna. W badaniach unaoczniły się także różnice w ocenie uczniów i nauczycieli dotyczące użyteczności wybranych treści nauczania w życiu zawodowym. Uczniowie częściej wskazywali: lokaty bankowe, rolę i funkcjonowanie banków w gospodarce, gospodarcze konsekwencje integracji 
Rycina 1. Wyniki badania dotyczącego zainteresowań podstawami przedsiębiorczości

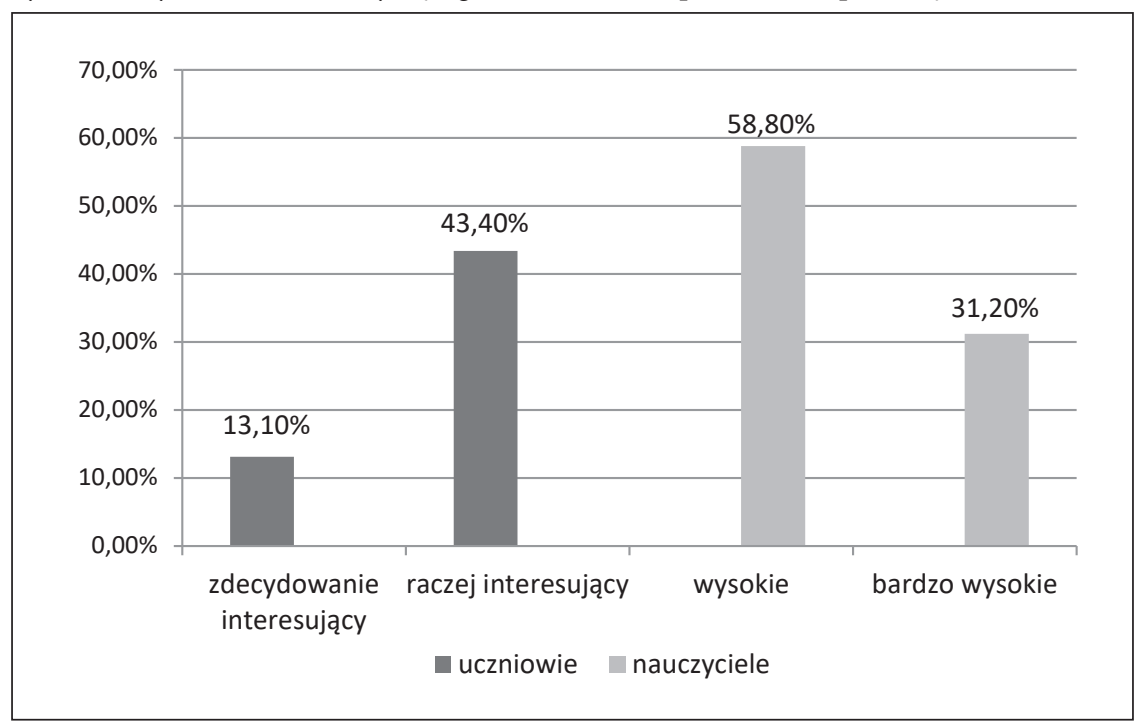

Źródło: opracowanie własne na podstawie: Kuklińska, Moranowski (2009)

Polski z Unią Europejską. Natomiast nauczyciele częściej sugerowali zagadnienia dotyczące: planowania i podejmowania działalności gospodarczej, rozwijania umiejętności związanych z poszukiwaniem pracy (Kuklińska, Moranowski, 2009, za: Tracz, 2015).

M. Tracz (2015) przeprowadziła pod koniec roku szkolnego 2012/2013 badania ankietowe wśród uczniów 13 liceów ogólnokształcących i 10 techników oraz wywiady z nauczycielami podstaw przedsiębiorczości. Badaniem objęła 734 uczniów klas pierwszych i nauczycieli. Celem badania było poznanie dwóch zagadnień:

- „opinii uczniów i nauczycieli o przedmiocie podstawy przedsiębiorczości, tj. ocenę jego rangi w szkole, przydatności i motywacyjnych aspektów poznawanych treści na lekcjach podstaw przedsiębiorczości,

- faktów dotyczących ważności edukacyjnej treści nauczania z podstaw przedsiębiorczości” (Tracz, 2015: 372).

Ze względu na zamierzony cel badań jednym z kluczowych pytań było pytanie dotyczące zainteresowania młodzieży przedmiotem podstawy przedsiębiorczości. Z uzyskanych przez M. Tracz wyników można wywnioskować, że 48,8\% uczniów liceów ogólnokształcących i 63,3\% uczniów z techników było zaciekawionych tym przedmiotem. W obu typach szkół około 1/4 badanych (LO: 22,7\%, T: 25,4\%) oznajmiało obojętność w stosunku do przedmiotu. Należy także zwrócić uwagę na fakt, że wzrosła liczba uczniów, którzy nie interesowali się przedmiot (LO: 13,4\%, T: 11,9\%). Dane zgromadzone przez M. Tracz dają więc podstawę do stwierdzenia, że zmiany podstawy programowej dokonane w 2009 r. oraz zwiększenie liczby godzin na nauczanie przedmiotu w porównaniu z innymi przedmiotami nie wpłynęły pozytywnie na postawę młodych ludzi wobec podstaw przedsiębiorczości. Wyniki badań $\mathrm{M}$. Tracz dowiodły też zauważoną przez innych badaczy zmianę w postrzeganiu przedmiotu przez uczniów szkół ponadgimnazjalnych, którzy częściej deklarowali brak zainteresowania przedmiotem - szczególnie proces ten nasila się w liceach ogólnokształcących (Tracz, 2015). 
Rycina 2. Zainteresowanie podstawami przedsiębiorczości uczniów LO i technikum

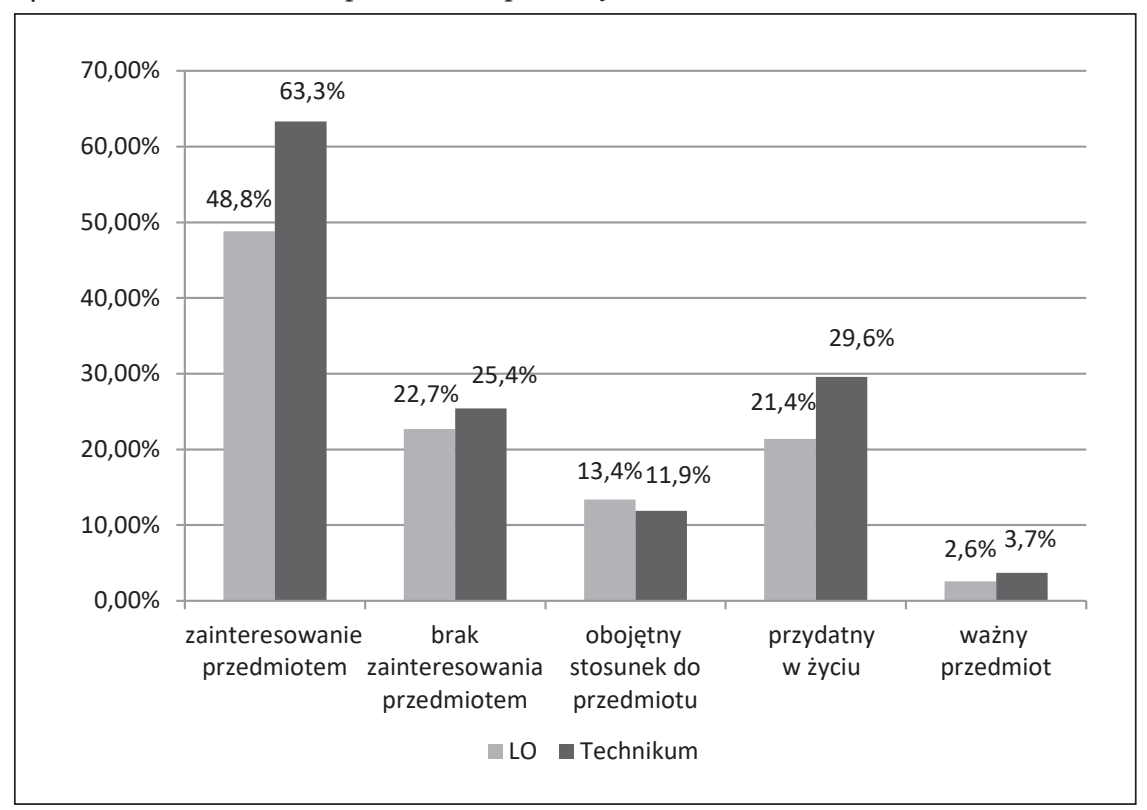

Źródło: opracowanie własne na podstawie: Tracz (2015)

Zdaniem M. Tracz (2015), interesujące wydają się także wypowiedzi uczniów szkół ponadgimnazjalnych o roli podstaw przedsiębiorczości w kształceniu ogólnym. Badaczka poprosiła uczniów o wypisanie przedmiotów szkolnych, które ich zdaniem są przedmiotami: ważnymi, interesującymi i przydatnymi w życiu codziennym. W tych trzech grupach najczęściej uczniowie szkół ponadgimnazjalnych podawali podstawy przedsiębiorczości w grupie przedmiotów przydatnych w życiu codziennym (LO: 21.4\%, T: 29,6\%). Natomiast niewielka liczba uczniów umieściła podstawy przedsiębiorczości w grupie przedmiotów ważnych (LO: 2,6\%, T: 3,7\%). W tej grupie ankietowani wymieniali najczęściej matematykę, język polski, język obcy i przedmioty profilu (Tracz, 2015).

Z zebranych przez M. Tracz (2015) danych wynika, że uczniowie technikum byli bardziej zainteresowani podstawami przedsiębiorczości i lepiej widzieli przydatność tego przedmiotu w życiu niż uczniowie liceów ogólnokształcących, dla których bardziej liczyły się przedmioty ogólnokształcące w ramach danego profilu (rycina 2).

Natomiast opinie nauczycieli o roli edukacyjnej przedmiotu zebrane przez M. Tracz różniły się od opinii uczniów. Podczas rozmowy nauczyciele sygnalizowali ciekawe treści omawiane na tym przedmiocie, co w ich ocenie powinno mieć wpływ na zainteresowanie nim młodzieży. Nauczyciele, podobnie jak uczniowie, byli zbieżni co do dużej użyteczności treści z podstaw przedsiębiorczości w życiu codziennym i dalszej karierze zawodowej (Tracz, 2015).

Na podstawie wywiadów przeprowadzonych przez M. Tracz w ankietowanych szkołach z nauczycielami przedsiębiorczości można stwierdzić, że nauczyciele także zauważają mniejsze zainteresowanie uczniów liceów ogólnokształcących problematyką poruszaną na lekcjach podstaw przedsiębiorczości, niż było to zaraz po wprowadzeniu przedmiotu do szkół. Okoliczności tej sytuacji dopatrują się m.in. w: 
Rycina 3. Źródła pozyskiwania wiedzy z zakresu ekonomii

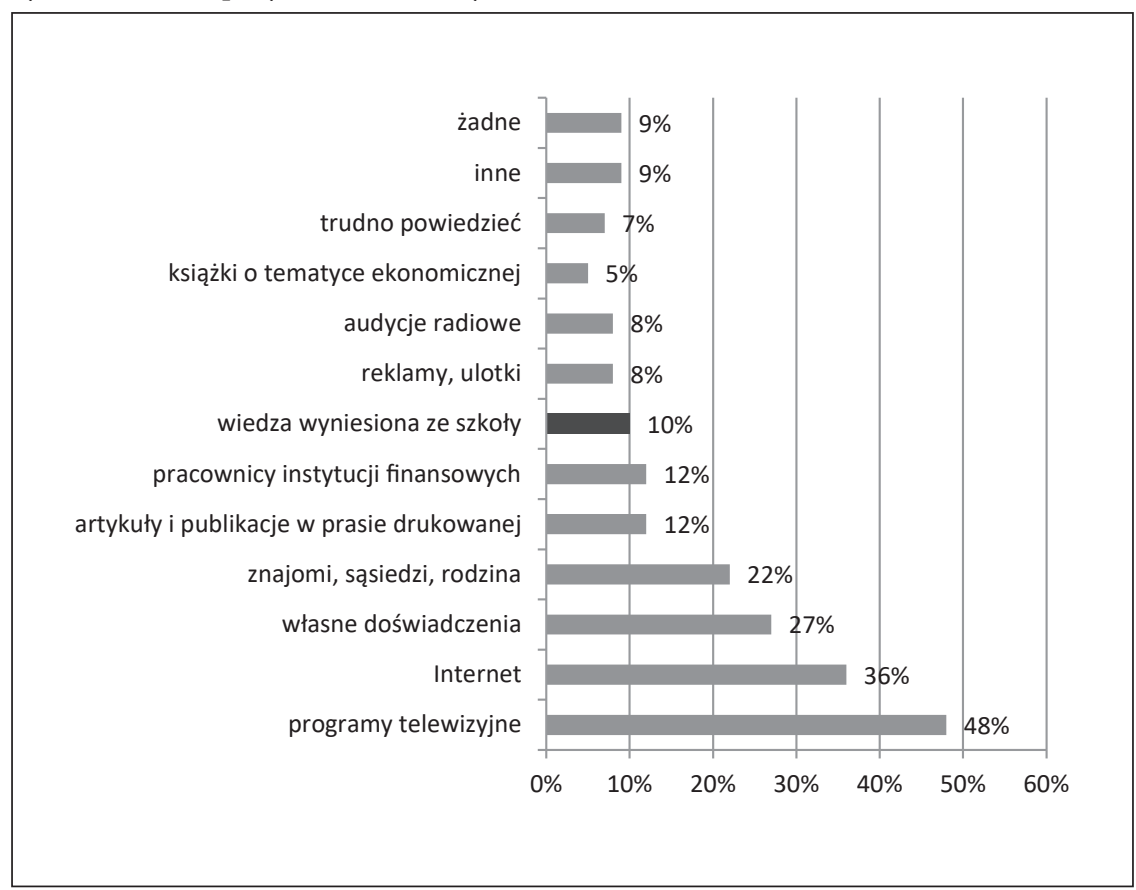

Źródło: opracowanie własne na podstawie: Wieczorek, Rec (2018)

- „zbyt wczesnym profilowaniu klas (25,6\%),

- odbieraniu tego przedmiotu przez uczniów jako mało ważnego (31,0\%),

- braku matury z tego przedmiotu $(23,5 \%)$,

- małym zainteresowaniu uczniów szkołą (12,3\%)" (Tracz, 2015: 396).

Wyniki badań własnych

Autorka niniejszego artykułu razem $\mathrm{z}$ innym badaczem przeprowadziła badania ankietowe na 1189 uczniach w 5 zróżnicowanych profilowo szkołach województwa łódzkiego, w tym w jednej szkole powiatowej. Badania dotyczyły oceny postaw i działań przedsiębiorczych, a także czy i jaki wpływ ma szkoła na rozwijanie umiejętności przedsiębiorczych oraz przygotowania do założenia i prowadzenia działalności gospodarczej.

Jedno z pytań dotyczyło pomagania szkoły w rozwijaniu umiejętności przedsiębiorczych. Uczniowie udzielali odpowiedzi w skali Likerta, gdzie: 1 - zdecydowanie nie, 2 raczej nie, 3 - trudno powiedzieć, 4 - raczej tak, 5 - zdecydowanie tak pomaga rozwijać umiejętności przedsiębiorcze. W zależności od profilu liceum wyniki są zróżnicowane, ale można powiedzieć, że najwięcej uczniów uważa, iż szkoła raczej pomaga w rozwijaniu umiejętności przedsiębiorczych (ryciny 4-8).

W liceum powiatowym 69\% wszystkich uczniów pozytywnie oceniło rozwijanie umiejętności przedsiębiorczych, tylko 5\% było zdania negatywnego. Najbardziej pozytywne odpowiedzi zauważalne są w klasie z rozszerzeniem biologiczno-chemiczno-matematycznym, gdzie dostrzegało to 3/4 uczniów. 
W liceum dziennikarsko-teatralno-filmowym uczniowie klasy teatralno-filmowej uważają, że szkoła pomaga rozwijać umiejętności przedsiębiorcze w 64\%, natomiast klasy dziennikarskiej - w 63\%.

W bardzo dobrym liceum, które ma wszystkie klasy z rozszerzeniem matematycznym, 72\% uczniów klasy matematyczno-fizyczno-językowej i 71\% uczniów klasy matematyczno-fizycznej uważało, że szkoła pomaga rozwijać umiejętności przedsiębiorcze. Najmniej (55\%) uczniów było tego zdania w klasie matematyczno-biologiczno-chemicznej. Niewielu uczniów uważało, że szkoła nie pomaga w rozwijaniu umiejętności przedsiębiorczych.

Uczniowie w liceum z rozszerzonymi klasami matematycznymi i jedną klasą humanistyczną uważali, że szkoła raczej pomaga (48\%) lub zdecydowanie pomaga (25\%) rozwijać umiejętności przedsiębiorcze. Najmniej pozytywnie wypowiedzieli się uczniowie klasy matematyczno-biologiczno-chemicznej.

W liceum zróżnicowanym profilowo najbardziej rozwijanie umiejętności przedsiębiorczych przez szkołę zauważyli uczniowie klasy sportowej (43\%), a najmniej - uczniowie grupy biologiczno-chemiczno-anglistycznej.

Podsumowując badania ankietowe na temat oceny umiejętności przedsiębiorczych, można wywnioskować, że uczniowie klas: sportowej, teatralno-filmowej, dziennikarskiej, geograficzno-językowej najbardziej doceniają wpływ szkoły na rozwój tych umiejętności. Uczniowie klas z rozszerzeniami matematyczno-fizycznymi i biologiczno-chemicznymi bardziej są skupieni na wybranych przez siebie profilach. Wydaje się, że wśród uczniów osiągających bardzo dobre wyniki w szkołach o wysokich pozycjach rankingowych, podstawy przedsiębiorczości w obecnej formie są przedmiotem praktycznym, ale mało konkretnym, bez porządnej podstawy teoretycznej, stąd ten wynik. Młodzież ma wyraźnie ustaloną i określoną ścieżkę swojej kariery zawodowej i na tym etapie nie oczekuje innych propozycji czy zmian. Zainteresowani swoimi specjalnościami i profilami, nie interesują się praktycznymi rozwiązaniami, na które być może przyjdzie czas w późniejszych latach. Uczniowie trzecich klas licealnych oznajmiali znacznie wyższe zaciekawienie tymi zagadnieniami niż ich koledzy z klas pierwszych. Niewątpliwie wiek, doświadczenie oraz dalsze plany związane z edukacją powodują, że uczniowie klas trzecich znacznie optymistyczniej postrzegają przedmiot podstawy przedsiębiorczości. Natomiast młodzież z klas pierwszych, która rozpoczyna edukację w nowej szkole, bardziej interesuje się i kieruje swoją uwagę na zajęcia związane z wybieranym profilem kształcenia. Według uczniów, podstawy przedsiębiorczości mają niską rangę w szkole, ponieważ nie jest to przedmiot maturalny.

Na rangę i ważność przedmiotów szkolnych dla kształcenia przedsiębiorczości zwrócił uwagę Z. Zioło (Zioło, 2011). Wprowadzenie zagadnień merytorycznych i zasadniczych z przedsiębiorczości na poszczególnych przedmiotach prowadzi do wszechstronnego oraz globalnego analizowania faktów i procesów. Stąd kolejne z pytań dotyczyło podania przedmiotów, na których rozwijane byłyby postawy przedsiębiorcze. Uczniowie widzą potrzebę realizowania treści również w ramach innych przedmiotów, nie tylko na podstawach przedsiębiorczości, a mianowicie: matematyka, wiedza o społeczeństwie, geografia, język polski, informatyka (rycina 9). 
Rycina 4. Ocena umiejętności przedsiębiorczych w zależności od profilu w liceum powiatowym

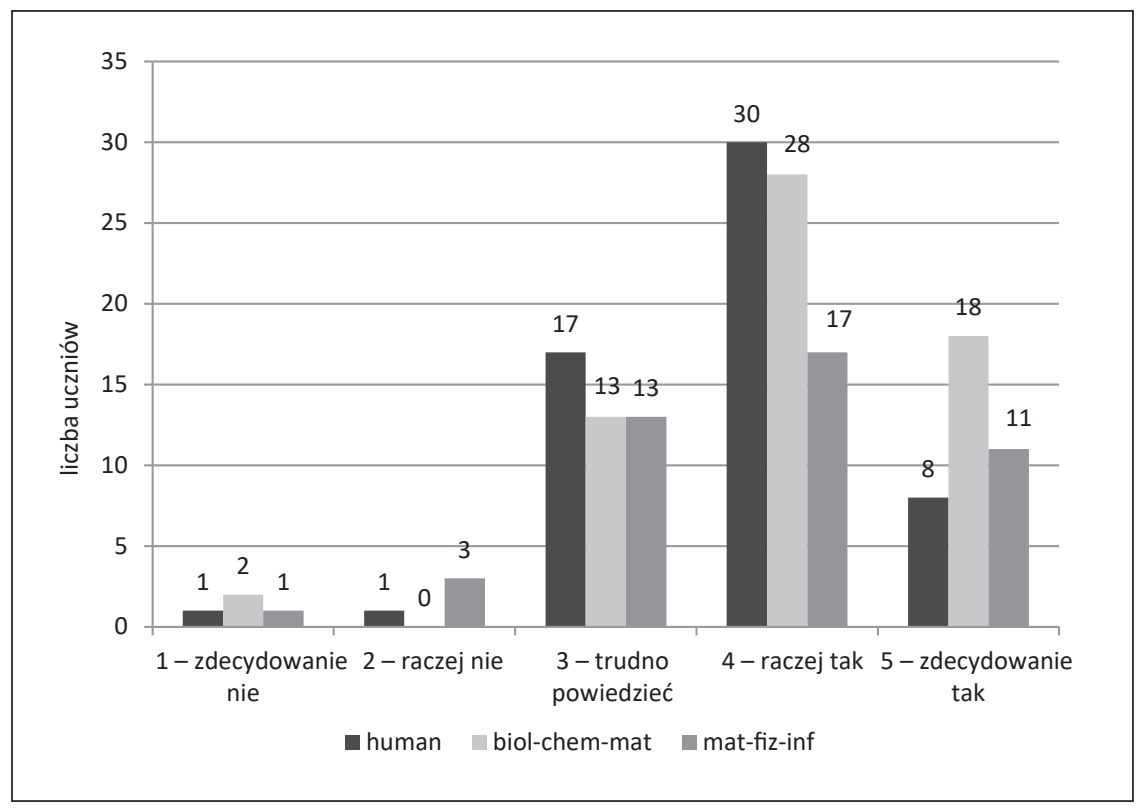

Źródło: opracowanie własne na podstawie badań ankietowych

Rycina 5. Ocena umiejętności przedsiębiorczych w zależności od profilu w liceum dziennikarsko-teatralno-filmowym

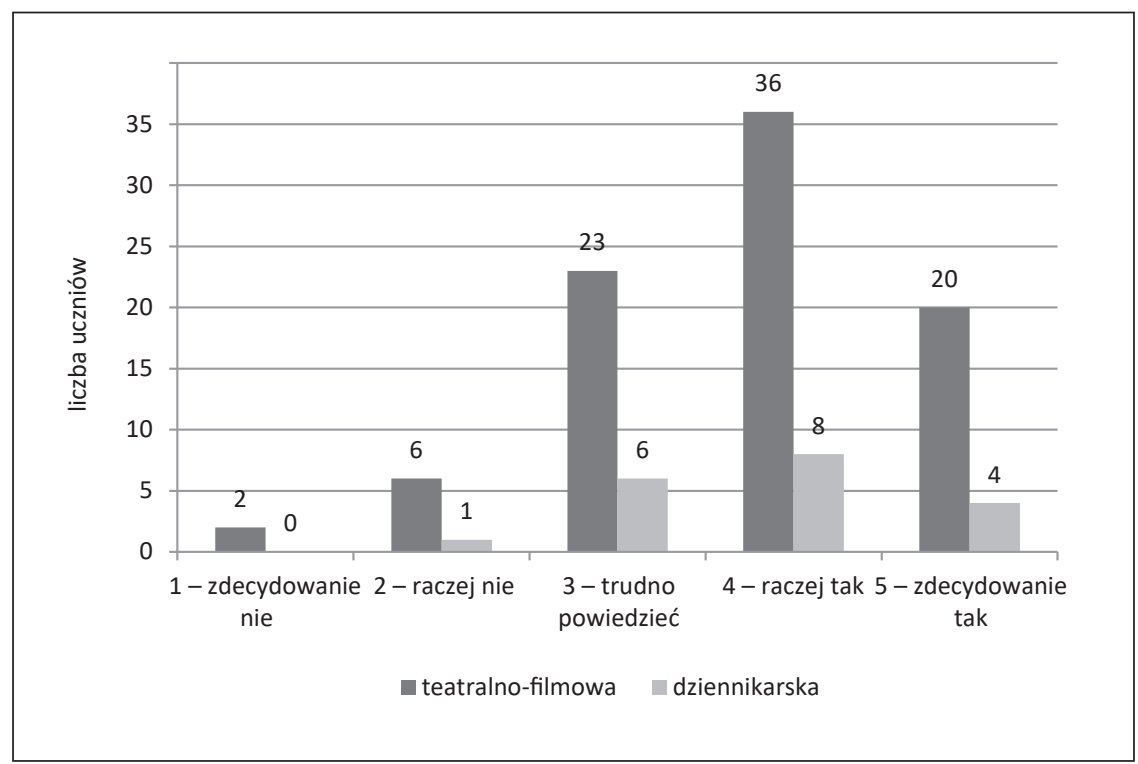

Źródło: opracowanie własne na podstawie badań ankietowych 
Rycina 6. Ocena umiejętności przedsiębiorczych w zależności od profilu w bardzo dobrym liceum $\mathrm{z}$ wszystkimi klasami z rozszerzoną matematyką

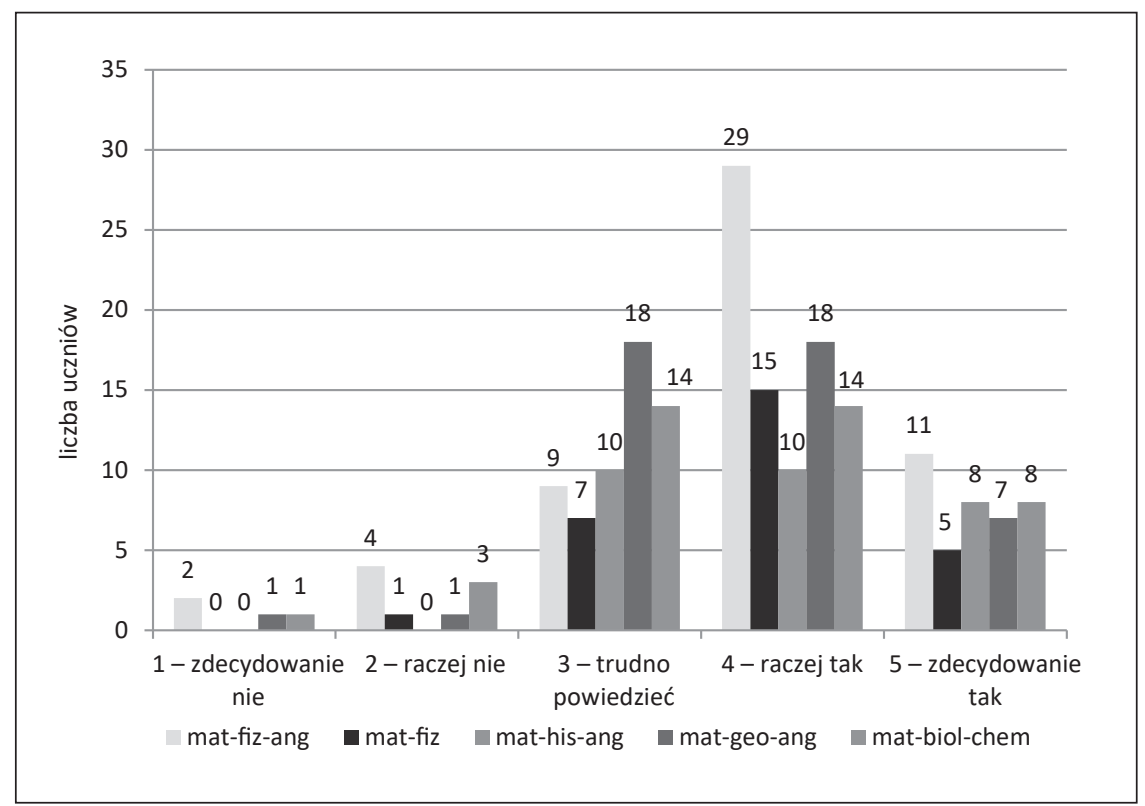

Źródło: opracowanie własne na podstawie badań ankietowych

Rycina 7. Ocena umiejętności przedsiębiorczych w zależności od profilu w liceum z rozszerzonymi klasami matematycznymi i jedną klasą humanistyczną

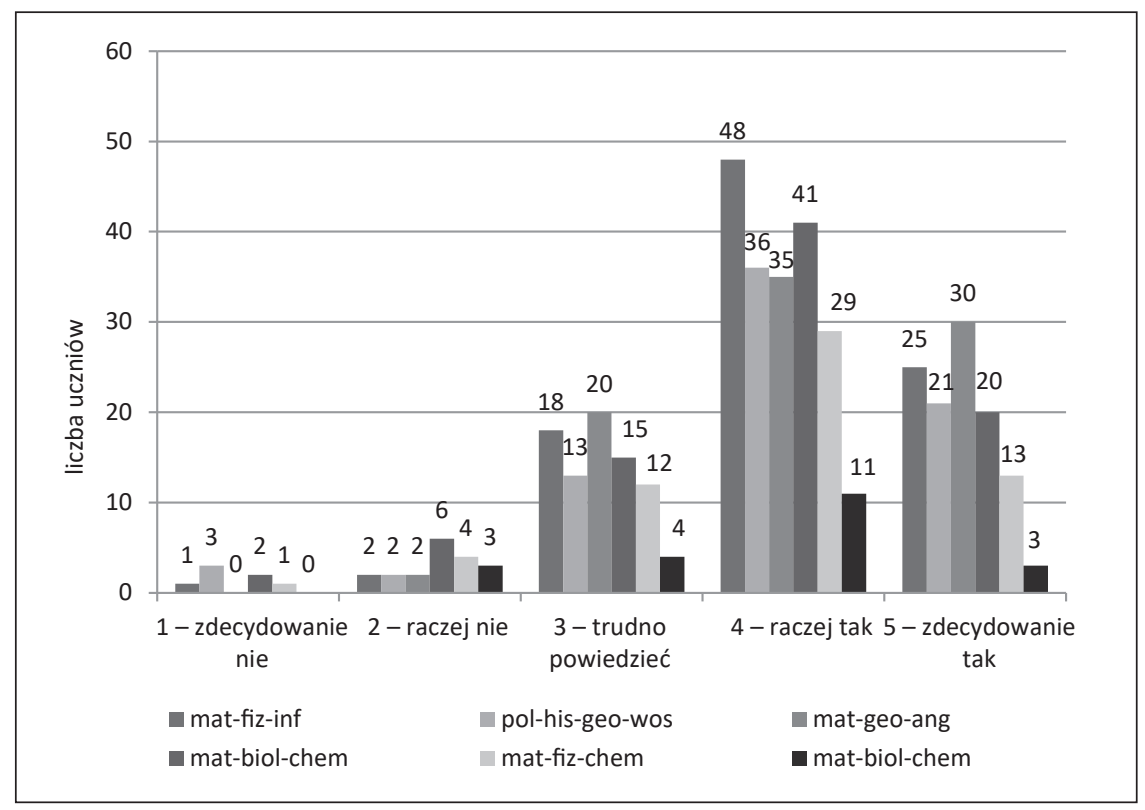

Źródło: opracowanie własne na podstawie badań ankietowych 
Rycina 8. Ocena umiejętności przedsiębiorczych w zależności od profilu w liceum z rozszerzonymi klasami matematycznymi i jedną klasą humanistyczną

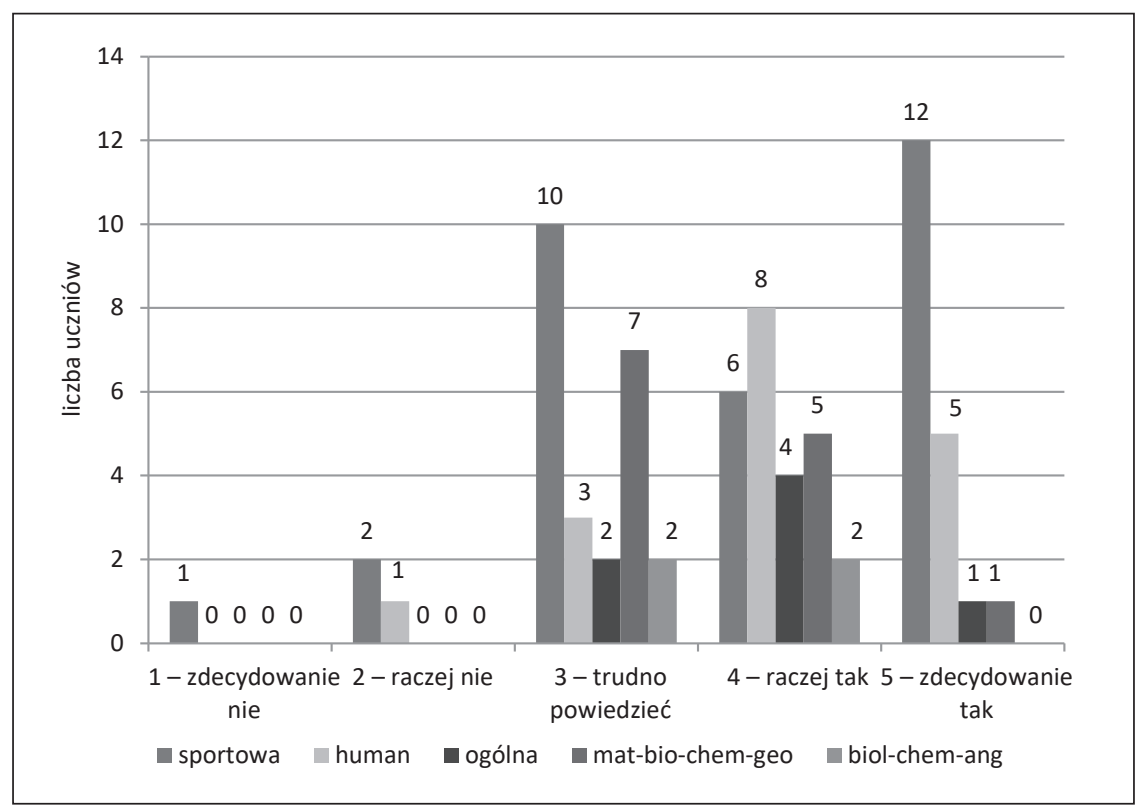

Źródło: opracowanie własne na podstawie badań ankietowych

Rycina 9. Przedmioty pomocne przy rozwijaniu postaw przedsiębiorczych

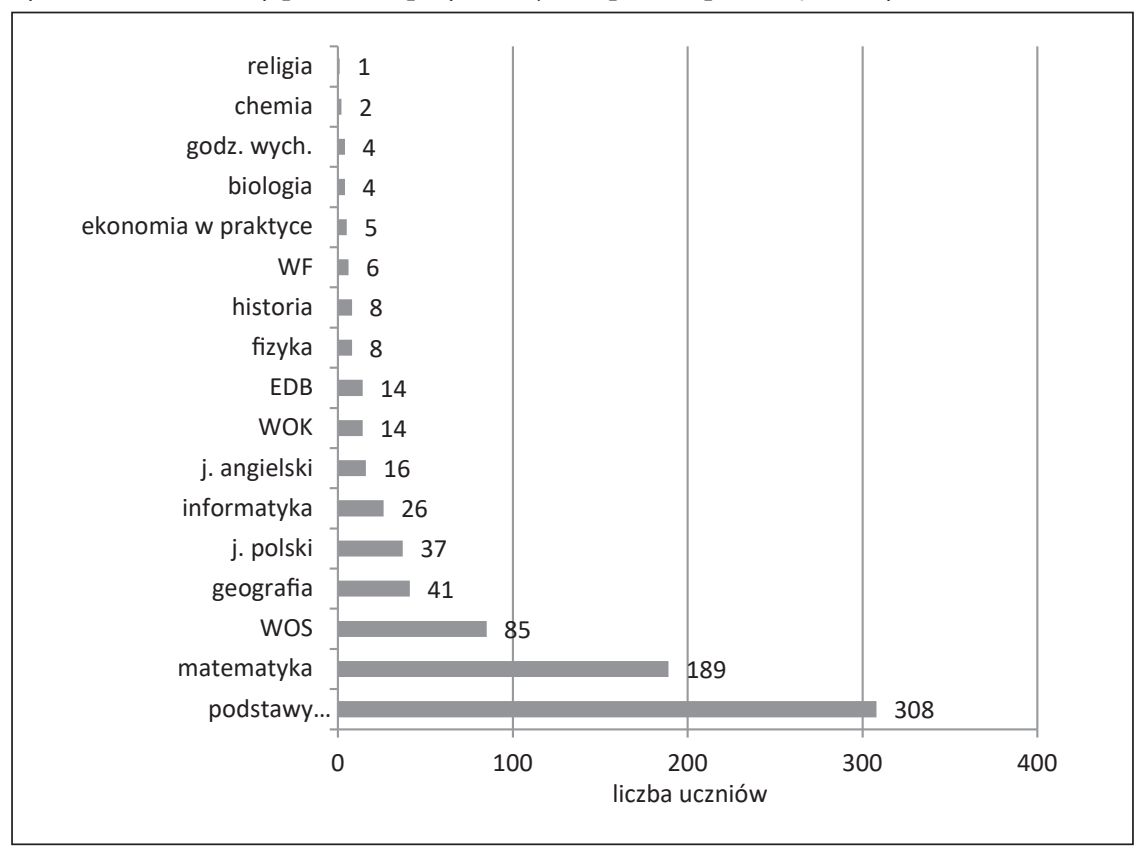

Źródło: opracowanie własne na podstawie badań ankietowych 


\section{Zakończenie}

Z przeprowadzonych badań związanych z zainteresowaniem uczniów podstawami przedsiębiorczości oraz jego pozycją w szkole ponadgimnazjalnej wynika, iż maleje ogólne przyzwolenie i aprobata dla wprowadzenia podstaw przedsiębiorczości do szkół ponadgimnazjalnych jako oddzielnego przedmiotu nauczania. W początkowym okresie było względnie wysokie pozytywne nastawienie wśród młodzieży, nauczycieli i rodziców, natomiast obecnie jest ono zdecydowanie mniejsze. Coraz więcej uczniów deklaruje brak zainteresowania tym przedmiotem. Najbardziej jest to widoczne w liceach ogólnokształcących. Młodzi ludzie z tych szkół, często mający już ustaloną i konkretną ścieżkę kariery nastawioną na dalsze kształcenie uniwersyteckie, nie są zainteresowani tak bardzo tym przedmiotem, jak ich koledzy w technikach. Dla uczniów ze szkół o profilu zawodowym podnoszona tematyka jest istotnym i konkretnym akcentem w przygotowaniu do życia zawodowego. Wielu z nich bezpośrednio po ukończeniu szkoły szuka zatrudnienia, co przypuszczalnie ma wpływ na ich większe zainteresowanie tematyką przedstawianą na lekcjach podstaw przedsiębiorczości.

Młodzież szkół ponadgimnazjalnych przypisuje treściom nauczania z podstaw przedsiębiorczości znaczącą wartość w życiu codziennym, mimo że potwierdza mniejsze zainteresowanie tym przedmiotem. Uczniowie uważają, że przydatne w kształceniu są tematy dotyczące m.in.: rynku pracy, zakładania własnej działalności gospodarczej oraz funkcjonowania wybranych instytucji finansowych.

Obecnie szkoła ponadgimnazjalna jest mocno sprofilowana i straciła charakter ogólnokształcący, stąd należy zastanowić się nad założeniami w zakresie przedsiębiorczości i ich praktyczną realizacją w szkole. „Istnieje wiele opracowań i raportów o podstawie programowej, celach i zadaniach kształcenia z podstaw przedsiębiorczości, ale stosunkowo niewiele miejsca poświęcono ocenom przyjętego rozwiązania systemowego. Na ile istniejący od 2002 r. osobny przedmiot w szkole ponadgimnazjalnej sprzyja realizacji zamierzonych celów pobudzania obywatelskiej przedsiębiorczości oraz odpowiada na potrzeby poznawcze uczniów oraz ogólne cele kształcenia?” (Tracz, 2015: 399)

Nauczanie w zakresie przedsiębiorczości w 2/3 badanych krajów jest realizowane na różnych poziomach kształcenia w zakresie przedmiotów społecznych, ekonomicznych lub matematycznych. Natomiast tylko w ośmiu krajach na poziomie szkoły średniej niższego stopnia wyłączono odrębny przedmiot, nierzadko jako przedmiot uzupełniający. Polska jest jedynym krajem w tej grupie, gdzie przedsiębiorczość jest obowiązkowym przedmiotem nauczania w szkole średniej wyższego poziomu - szkole ponadgimnazjalnej, obecnie szkole ponadpodstawowej (Tracz, 2015).

Z przeprowadzonych do tej pory badań wynika, że przedmiot podstawy przedsiębiorczości nadal spełnia wymagania większości ankietowanych uczniów i rodziców. Tym samym zauważa się zaniepokojenie rodziców o przyszłość dzieci związaną z umiejętnością działania w życiu społeczno-gospodarczym w gospodarce wolnorynkowej. Z czasem okaże się, czy zaproponowane zmiany w podstawie programowej szkoły ponadgimnazjalnej, a od roku szkolnego 2019/2020 - ponadpodstawowej, podstaw przedsiębiorczości wyjdą na przekór wszystkim uczniom, również tym wybitnie zdolnym, i czy zainteresowanie przedmiotem oraz zastosowanie treści kształcenia przedsiębiorczości i umiejętności przedsiębiorczych w karierze zawodowej będzie większe. Uważa 
się za bardzo ambitne wskazanie współczesnej szkole zadania wykształcenia młodych ludzi, którzy będą potrafili odnaleźć się w czasie transformacji systemowej.

Zgadzając się z S. Wieczorkiem (Wieczorek, Rec, 2018), autorka widzi potrzebę zmiany sposobu nauczania podstaw przedsiębiorczości. Obecny system edukacji przedsiębiorczej czy ekonomicznej nie jest przystosowany do obecnej rzeczywistości oraz potrzeb młodych osób. Jak zostało powyżej przedstawione, wiedza z zakresu ekonomii i finansów jest nieodłącznym elementem naszego życia, a zatem świadomość w tym zakresie powinna być istotna dla każdego człowieka. Zaproponowane poprawki są ważne na tyle, że właśnie ta wiedza pomaga kształtować prawidłowe postawy oraz inspiruje rozwój obywatelskiego społeczeństwa poprzez przemyślane wybory. Ponadto, właściwe i poprawne podstawy nie tylko pozwolą na podejmowanie rozsądnych decyzji w świecie finansów, ale też ułatwią urzędom państwowym ochronę konsumentów. Ważne jest, by przekazywana wiedza miała sprawdzone i wiarygodne źródło, tak aby tematyka nie wywoływała sprzeciwu odbiorców oraz nie stanowiła narzędzia kombinacji przez różne instytucje. Należy zaznaczyć, że „dużą wątpliwość Polaków budzi charakter przekazywanych treści ekonomicznych, zwłaszcza z perspektywy etyki” (Górski, 2016: 3). Dlatego też, szkolna edukacja powinna być fundamentalnym źródłem wiedzy, zapewniającym obiektywizm przekazywanej wiedzy.

Edukacja jest procesem, który nie powinien ustawać przez całe życie. Im wcześniej ten proces jest rozpoczęty, tym większe oczekiwane profity. Poprawne nawyki z młodych lat przynoszą zyski przez całe życie. Według teorii behawioralnej, łatwiej jest nauczyć właściwych nawyków osoby młode, niż oduczać złych nawyków osoby starsze. Osoby bardziej światłe i z nabytą wiedzą w tym zakresie podejmują racjonalniejsze decyzje związane z zarządzaniem pieniędzmi. Obecnie wielu nauczycieli zajmuje się edukacją ekonomiczną, czyli nie uczy postaw przedsiębiorczych, zaradności, samodzielności, tylko przekazuje wiedzę o systemie gospodarczym i o gospodarce. Współcześnie młodzi ludzie funkcjonują w systemie gospodarki rynkowej od urodzenia, zatem należałoby wprowadzić rozumienie i interpretowanie danych oraz ich analizowanie od lat możliwie jak najwcześniejszych. Zasadne jest, aby uczyć przedsiębiorczości już od szkoły podstawowej, tak jak jest to czynione w wielu krajach, oraz dokonać zmian w zakresie „wiedzy, umiejętności i postaw przedsiębiorczych” w programach nauczania w szkolnictwie polskim. Następnie w szkole ponadpodstawowej, nie tylko na podstawach przedsiębiorczości czy ekonomii w praktyce, ale również na innych przedmiotach. Wskazane byłoby, aby ekonomia była jednym z przedmiotów do wyboru na maturze, wówczas ten przedmiot miałby większą rangę, a (w ostateczności) maturzysta nie musiałby się zastanawiać czy przygotowywać się do matury czy olimpiady.

Literatura

References

Bartman, K. (2008; 2018, 20 sierpnia). Matura z przedsiębiorczości za siedem lat. Pozyskano z: http:// praca.gazetaprawna.pl/wywiady/95660,matura_z_przedsiebiorczosci_za_siedem_lat

BIK. (2017, 20 kwietnia). Świadomość finansowa - słaby punkt młodych Polaków. Pozyskano z: http:// media.bik.pl/informacje-prasowe/352565/swiadomosc-finansowa-slaby-punkt-polakow

Dąbrowski, M. (2011). Ekonomia w praktyce - nowy przedmiot nauczania. E-mentor, 4(41).

Dąbrowski, M. (2012). Edukacja na rzecz przedsiębiorczości a rozwój gospodarczy. Optimum. Studia ekonomiczne, 3(57), 159-172. 
Górski, J. (2016). Alfabetyzacja ekonomiczna, czyli znaczenie świadomości ekonomicznej. Bezpieczny Bank, 3.

Klapper, L., Lusardi, A., van Oudheusden, P. (2015). Financial Literacy Around the World: Insights from the Standard \& Poor's Services. Global Financial Literacy Survey.

Komisja Wspólnot Europejskich. (2006). Komunikat Komisji Wspólnot Europejskich: Realizacja wspólnotowegoplanulizbońskiego. Rozbudzenieduchaprzedsiębiorczościpoprzezedukacjęikształcenie.Pozyskano z: https://eur-lex.europa.eu/legal-content/PL/TXT/PDF/?uri=CELEX:52006DC0033\&from=SL

Kuklińska, K., Moranowski, P. (2009). Przedmiot podstawy przedsiębiorczości oczami nauczycieli i uczniów szkół ponadgimnazjalnych. Raport z badań. Pozyskano z: www.file/C:Users/nicon/ Dowlands/Raport\%20badan.pdf

Kurek, Z. (2001). Przedsiębiorczość. Poradnik metodyczny dla nauczycieli. Olsztyn: Wydawnictwo OWSIZ.

Makieła, Z., Rachwał, T. (2007). Podstawy przedsiębiorczości. Poradnik metodyczny. Warszawa: Nowa Era.

Ministerstwo Edukacji Narodowej (2018, 12 listopada). Podstawa programowa $z$ podstaw przedsiębiorczości. Pozyskano z: https://podstawaprogramowa.pl/Liceum-technikum/Podstawyprzedsiebiorczosci

Nauczanie podstaw przedsiębiorczości w szkole: programy, strategie. Raport Komisji Europejskiej. (2012). EURYDICE, Komisja Europejska. Pozyskano z: https://eurydice.org.pl/wp-content/ uploads/2017/01/PL_Entrepreneurship-Education.pdf

Osuch, E., Osuch, W. (2005). Przedmiot podstawy przedsiębiorczości w opinii uczniów i rodziców. Przedsiębiorczość - Edukacja, 1, 195-202.

Osuch, W. (2012). Podstawy przedsiębiorczości w opinii uczniów krakowskich szkół - szansa i oczekiwania. Przedsiębiorczość - Edukacja, 8, 37-46.

Rachwał, T. (2009). Ocena projektu zmian podstawy programowej podstaw przedsiębiorczości (przedstawiona przez MEN w 2008 r. w ramach reformy systemu oświaty), Przedsiębiorczość - Edukacja, $5,349-372$.

Raport zbiorowy $z$ badań środowisk szkolnych $w$ zakresie realizacji edukacji ekonomicznych $w$ polskich szkołach ponadgimnazjalnych. (2005). Warszawa: CODN.

Tracz, M. (2015). Przedmiot podstawy przedsiębiorczości w opinii uczniów i nauczycieli - studium porównawcze. Przedsiębiorczość - Edukacja, 11, 391-400.

Wachowiak, P., Dąbrowski, M., Majewski, B. (red.). (2007). Kształtowanie postaw przedsiębiorczych a edukacja ekonomiczna. Warszawa: Fundacja Promocji i Akredytacji Kierunków Ekonomicznych.

Wieczorek, S., Rec, W. (2018). Program poprawy świadomości ekonomiczno-finansowej Polaków: Rekomendacje zmian w systemie szkolnictwa obowiazkowego. Pozyskano z: https://oszczedzanienaetacie.pl/wp-content/uploads/2018/07/Raport-Program-poprawy-\%C5\%9Bwiadomo\%C5\%9Bciekonomiczno-finansowej-Polak\%C3\%B3w_FEDK.pdf

Zioło, Z. (2012). Miejsce przedsiębiorczości w edukacji. Przedsiębiorczość - Edukacja, 8, 10-23.

Ziółkowska-Weiss, K. (2014). Problematyka podstaw przedsiębiorczości w opinii uczniów szkoły ponadgimnazjalnej. Przydatność w życiu czy konieczność Przedsiębiorczość - Edukacja, 10, 366376.

Alina Błaszczyk, mgr, doktorantka na Wydziale Zarządzania, w Katedrze Zarządzania Zasobami Ludzkimi na Uniwersytecie Łódzkim oraz nauczycielka (podstaw przedsiębiorczości, matematyki, informatyki) w XII Liceum Ogólnokształcącym w Łodzi. Koordynator wojewódzki SIGG, certyfikowany trener w zakresie edukacji rynku kapitałowego. Od 2004 r. jej zainteresowania naukowe związane są z elektronicznymi platformami edukacyjnymi oraz kreowaniem postaw przedsiębiorczych wśród uczniów szkół ponadgimnazjalnych w świetle kompetencji poszukiwanych przez pracodawcę. 
Alina Błaszczyk, University of Lodz Department of Management Department of Human Resource Management, teacher at the XII High School in Lodz. Teacher (Basics of Entrepreneurship, mathematics, IT), provincial coordinator SIGG, certified trainer of capital market education. Since 2004, her research interests have been associated with entrepreneurship and electronic learning platforms. The author is a PhD student at the University of Lodz, Faculty of Management, and her research interests are related to creating entrepreneurial attitudes among high school students in the light of competences sought by the employer.

ORCID: 0000-0003-4032-3130

\section{Adres/Address:}

XII Liceum Ogólnokształcące im. S. Wyspiańskiego

al. Anstadta 7

91-409 Łódź, Polska

e-mail: alinab5@o2.pl 